\title{
Recenzja
}

\section{Dariusz Dudek, Autorytet Prezydenta a Konstytucja Rzeczypospolitej Polskiej, Wydawnictwo KUL, Lublin 2013, s. 340}

Praca Dariusza Dudka dotyka rzadko poruszanego w piśmiennictwie aspektu funkcjonowania prezydentury w Polsce, jakim jest zadanie czuwania nad przestrzeganiem Konstytucji, aktualnie powierzone głowie państwa na mocy art. 126 ust. 2 ustawy zasadniczej. Tytuł pracy stanowi wyraz przekonania autora, iż autorytet prezydenta RP - w jaki swoiście wyposaża go Konstytucja - czyniąc go „najwyższym przedstawicielem RP” i dając mu silną legitymację do sprawowania urzędu, pochodzącą z wyboru przez Naród - pozostaje w „sprzężeniu zwrotnym” (s. 17) z samą Konstytucją i koniecznością zapewnienia jej należnego autorytetu i poszanowania.

Recenzowana pozycja została podzielona na trzy rozdziały, poprzedzone „Wprowadzeniem ” i zamknięte „Zakończeniem”. Konstrukcję pracy uznać należy za przejrzystą. Co istotne, we „Wstępie” autor w sposób czytelny przedstawia cele, jakie stawiał sobie w pracy nad książką, oraz wyjaśnia jej tytuł. Jasno również wskazuje, jakie kwestie pozostawił poza obszarem swej refleksji.

Pierwszy rozdział zawiera charakterystykę pozycji ustrojowo-prawnej prezydenta RP w świetle Konstytucji RP z 1997 r. Należy przy tym podkreślić, iż rozważania zawarte $\mathrm{w}$ tej części pracy są przejrzyste i syntetyczne, choć w mojej ocenie zbędne było dość szczegółowe omawianie zasad wyborów na urząd prezydenta. Za trafne należy uznać wyrażone w tej części pra- 
cy stanowisko autora, iż pomimo formalnego zaliczenia prezydenta do organów władzy wykonawczej jego zadania w tej sferze są dość zdeprecjonowane, zaś na czoło wysuwają się powierzane mu zadania o charakterze gwarancyjnym. Szkoda jednak, iż D. Dudek nie podjął także próby odpowiedzi na pytanie, czy umieszczenie prezydenta wśród organów egzekutywy, a tym samym włączenie go do prowadzenia bieżącej polityki, nie jest czynnikiem utrudniającym mu skuteczną ochronę ustawy zasadniczej. Nie rozważył on również szczegółowo, na ile na wykonywanie przez prezydenta zadania czuwania nad przestrzeganiem Konstytucji wpływ wywiera przyjęty sposób obsady tego urzędu - a przecież oddziaływanie tego czynnika nie musi być wyłącznie pozytywne (choć jego zalety w budowaniu autorytetu głowy państwa są niezaprzeczalne) - choćby z uwagi na (podkreśloną zresztą w pracy) okoliczność, iż kandydat bezpartyjny w praktyce nie ma szans na zwycięstwo w wyborach powszechnych.

Rozdział II jest zasadniczy dla treści całej książki i zawiera omówienie funkcjonowania urzędu prezydenta jako gwaranta Konstytucji III RP. W pierwszej jego części autor szczegółowo zarysowuje tło historyczne kompetencji gwarancyjnych polskiej głowy państwa. Za mankament tej części pracy uważam brak szerszej analizy uchwały Rady Państwa PRL z dnia 14 lipca 1979 r. w sprawie czuwania nad zgodnością prawa z Konstytucją oraz ustalania powszechnie obowiązującej wykładni ustaw. Podzielam oczywiście pogląd autora, iż uchwała ta w realiach politycznych PRL nie miała praktycznego znaczenia, jednakże z uwagi na jej precedensowy charakter zasługiwała ona moim zdaniem na szersze omówienie.

W drugiej części rozdziału II została podjęta próba rekonstrukcji normatywnej treści prezydenckiego zadania czuwania nad przestrzeganiem Konstytucji. Słuszna jest przy tym konstatacja autora, iż skuteczna ochrona ustawy zasadniczej przez prezydenta może mieć miejsce jedynie wówczas, gdy zostanie on wsparty odpowiednim aparatem pomocniczym. Za trafny należy również uznać wniosek, iż sformułowanie o „przestrzeganiu Konstytucji” należy zawsze odnosić do konkretnych stanów faktycznych, nie zaś do abstrakcyjnych kwalifikacji. Wątpliwości budzi natomiast wskazanie, iż prezydent winien stać na straży nie tylko litery prawa, ale i „zasad i wartości ustawy zasadniczej” (s. 187). Problem bowiem w tym, iż stawianie „wartości konstytucyjnych" na równi z normami konstytucji jest dyskusyjne, 
a to $\mathrm{z}$ uwagi na trudność określenia ich relacji do tychże norm ${ }^{1}$. Uznanie zatem, że prezydencki obowiązek ochrony Konstytucji rozciąga się także na owe wartości, może rodzić w praktyce wątpliwości, nad czym w zasadzie głowa państwa ma czuwać.

Kolejna część rozdziału II została poświęcona analizie instrumentarium prawnego służącego głowie państwa do realizacji ochrony ustawy zasadniczej. Rozważania D. Dudka koncentrują się przy tym na kompetencji do inicjowania prewencyjnej kontroli konstytucyjności ustaw. Takie ujęcie nie może zaskakiwać. W pełni zgodzić się bowiem należy z autorem, iż kompetencja ta stanowi swoiste ,jądro" omawianego zadania prezydenta. Na aprobatę zasługuje oczywiście wyrażony w pracy pogląd, iż uruchomienie takiej kontroli jest bezwzględnym obowiązkiem prezydenta, w sytuacji gdyby powstały u niego istotne wątpliwości co do konstytucyjności ustawy przedłożonej mu do podpisu. To stanowisko nabiera szczególnego znaczenia wobec rysującej się w ostatnim okresie praktyki podpisywania ustaw przez głowę państwa i kierowania ich do TK w drodze kontroli następczej, mimo iż wątpliwości natury konstytucyjnej co do tych aktów normatywnych istniały jeszcze przed ich podpisaniem. D. Dudek zasadnie wskazuje, iż takie działania prowadzą do relatywizacji ochrony ustawy zasadniczej przez głowę państwa.

Ostatnia część drugiego rozdziału zawiera omówienie realizacji ochrony Konstytucji przez prezydenta. Omówienie to jest jednak ograniczone do dwóch kompetencji, tj. inicjatywy ustawodawczej i inicjowania prewencyjnej kontroli konstytucyjności ustaw. Niewątpliwie taki zabieg jest uzasadniony znaczeniem tych właśnie instrumentów w praktyce ustrojowej. W moim przekonaniu na odrębne omówienie zasługiwała jednak także choćby kompetencja do zlecania NIK przeprowadzenia kontroli. Trzeba przy tym zaznaczyć, iż autor już we „Wstępie” zaznaczył, iż jego celem jest „przykładowa (...) prezentacja” (s. 14) realizacji gwarancyjnych zadań prezydenta. Mimo tego zastrzeżenia uważam jednak, iż mankamentem tej części pracy jest ograniczenie wyliczenia inicjatyw ustawodawczych głowy państwa tylko do okresu pełnienia urzędu przez obecnego i poprzedniego prezydenta, podczas gdy jeśli chodzi o wnioski do TK w trybie kontroli pre-

1 P. Tuleja, Stosowanie Konstytucji RP w świetle zasady jej nadrzędności (wybrane problemy), Kraków 2003, s. 267-268; K. Działocha, Komentarz do art. 8 Konstytucji RP, [w:] Konstytucja Rzeczypospolitej Polskiej. Komentarz, t. V, red. L. Garlicki, Warszawa 2007, s. 17-20. 
wencyjnej, omówione zostały wszystkie takie przypadki od 1989 r. Autor zrezygnował również świadomie, co zaznaczył już we „Wstępie”, z „ewaluacji oceniania praktyki instytucjonalnej w aspekcie personalnym"(s. 14) nie chcąc się narazić na zarzut braku bezstronności. Z jednej strony wypada docenić taką postawę. Z drugiej jednak zauważyć trzeba, że prawo konstytucyjne funkcjonuje w ścisłym zespoleniu z praktyką polityczną i stąd analiza funkcjonowania jego rozwiązań nie może nie uwzględniać także czynników pozanormatywnych.

Trzeci i ostatni rozdział pracy zatytułowany jest „Spór o polski model prezydentury”. Pierwsza jego część została poświęcona omówieniu trzech kontrowersyjnych zagadnień prawnych dotyczących prezydenta RP, tj. sporu kompetencyjnego pomiędzy prezydentem a prezesem Rady Ministrów rozstrzygniętego orzeczeniem TK o sygn. Kpt 2/08, kwestii kontrasygnaty aktów urzędowych głowy państwa oraz statusu prezydenta w dziedzinie dostępu do informacji publicznej. Przy omawianiu pierwszego z zagadnień przyjęto przy tym metodę przedstawienia argumentacji zawartej we wniosku premiera do TK o rozstrzygnięcie sporu kompetencyjnego oraz w stanowisku prokuratora generalnego przedstawionym w tym postępowaniu, $\mathrm{z}$ jednoczesnym prezentowaniem przez autora kontrargumentów do zawartych w tych pismach poglądów. Całość wywodu D. Dudka jest przy tym bardzo przejrzysta. W moim przekonaniu konsekwentnie, w sposób dobrze uargumentowany i logiczny autor przedstawia swoje stanowisko, i co najważniejsze, celnie wyszukuje różnego rodzaju błędy i sprzeczności w argumentacji wniosków premiera i prokuratora generalnego, wykazując, iż zmierzały one do nieuzasadnionej niczym deprecjacji pozycji ustrojowej prezydenta. Orzeczenia TK zapadłego w przedmiotowej sprawie autor w żaden sposób jednak nie komentuje, uznając, iż nie jest do tego uprawniony, gdyż był w trakcie tegoż postępowania pełnomocnikiem prezydenta. Niewątpliwie tego rodzaju powściągliwość zasługuje na uznanie, jednakże brak odniesienia się do stanowiska TK sprawia, iż ta część pracy pozostaje bez przysłowiowej „kropki nad i”, co pozostawia jednak spore uczucie niedosytu.

Rozważania autora dotyczące kontrasygnaty skupione są na powoływaniu przez prezydenta prokuratora generalnego i jego zastępców oraz jednego członka Krajowej Rady Prokuratury. D. Dudek wyraża przy tym stanowisko, iż akty te winny być zwolnione od kontrasygnaty, gdyż premier nie 
powinien mieć wpływu na obsadę tych stanowisk. Tym samym, w jego ocenie funkcjonalna i celowościowa wykładnia Konstytucji winna przemawiać za odejściem od literalnej interpretacji art. 144 ust. 3 pkt. 1-30 Konstytucji, w myśl której wszystkie akty urzędowe prezydenta niezawarte w tym katalogu wymagają kontrasygnowania przez szefa rządu. W tym ujęciu powołanie w 2010 r. przez prezydenta B. Komorowskiego członka Krajowej Rady Prokuratury bez podpisu premiera było w ocenie autora posunięciem zgodnym z prawem. Zgadzam się z D. Dudkiem, iż część niezamieszczonych w art. 144 ust. 3 pkt. 1-30 Konstytucji kompetencji winna być zwolniona od kontrasygnaty. Jednak w moim przekonaniu postulat ten jest trafny tylko i wyłącznie na płaszczyźnie de lege ferenda. Nie można bowiem odchodzić od zasady exceptiones non sunt extendendae tylko dlatego, że rezultaty jej stosowania uważamy za nietrafne. Ewentualnych niekonsekwencji ustrojodawcy nie można naprawiać w drodze zabiegów interpretacyjnych, które same prowadzą do naruszenia Konstytucji. Nadto podkreślić należy, iż obowiązek czuwania nad przestrzeganiem ustawy zasadniczej obliguje prezydenta do dochowania należytej staranności, by samemu nie przekroczyć jej norm. Tym samym prezydent winien również zatroszczyć się o to, by akt urzędowy wymagający podpisu prezesa Rady Ministrów został weń zaopatrzony. W razie zaś kontrowersji co do zakresu kontrasygnaty, powinien on przyjąć, iż jest ona konieczna. Jako organ czuwający nad przestrzeganiem Konstytucji głowa państwa nie może bowiem świadomie podejmować działań, co do których ma świadomość, iż niosą ze sobą znaczne ryzyko naruszenia ustawy zasadniczej, a tak niewątpliwie jest w sytuacji niepewności co do zakresu kontrasygnaty. $\mathrm{W}$ rozważaniach o kontrasygnacie autor nie zauważył również, iż analogiczny problem do nominacji prezydenckiego przedstawiciela w Krajowej Radzie Prokuratury już od dawna miał miejsce także odnośnie do przedstawiciela głowy państwa w Krajowej Radzie Sądownictwa - którego już od dawna konsekwentnie powoływano i odwoływano bez kontrasygnaty.

Ponieważ recenzowana publikacja została oddana do druku przed wydaniem przez TK wyroku w sprawie P 25/12, zawarte w niej rozważania dotyczące statusu prezydenta w dziedzinie dostępu do informacji publicznej nie zawierają analizy tego orzeczenia. Cechuje je wszakże dogłębne rozważanie różnych aspektów tejże problematyki. Autor w moim przekonaniu poda- 
je przekonujące argumenty, iż obowiązku udzielania informacji publicznej przez prezydenta nie należy bezwzględnie rozciągać na cały proces prowadzący do podjęcia przez niego danej decyzji, albowiem opinie i ekspertyzy zamówione przez głowę państwa nie mieszczą się w żadnej z kategorii wskazanych art. 6 ust. 1 ustawy o dostępie do informacji publicznej.

Druga część rozdziału III zawiera omówienie dwóch projektów zmian w Konstytucji RP z 2010 r. - poselskiego (druk sejmowy nr 2989) i prezydenckiego (druk sejmowy nr 3598). Autor przeprowadza bardzo szczegółową analizę obydwu wyżej wymienionych propozycji, momentami wręcz rozbierając zawarte w nich sformułowania na przysłowiowe „czynniki pierwsze”. Drugi z projektów mimo pewnych uwag krytycznych ocenia on generalnie pozytywnie, jednocześnie nie ukrywając swego negatywnego stosun$\mathrm{ku}$ do pierwszego $\mathrm{z}$ nich, o czym świadczy fakt, iż w tytule podrozdziału określa go jako „degradację autorytetu głowy państwa”. Argumentacja autora $\mathrm{w}$ tej kwestii jest zresztą w wielu miejscach przekonująca. M.in. trafnie $\mathrm{w}$ moim przekonaniu uwypuklił on, iż zawarta w nim propozycja zmiany art. 179 Konstytucji, poprzez wskazanie, że prezydent może odmówić powołania na stanowisko sędziowskie kandydata zaproponowanego przez KRS tylko „Z ważnych powodów”, nie rozstrzygnęłaby kontrowersji związanych z tym przepisem - gdyż pojęcie „ważne powody” również jest nieostre, a ponadto nie zostało wskazane, kto miałby ową „ważność” oceniać.

W „Zakończeniu” autor zawarł kilka postulatów de lege ferenda - mających przyczynić się do skuteczniejszego wykonywania przez prezydenta zadania ochrony Konstytucji. Niektóre z nich zasługują moim zdaniem na poparcie. Mam tu na myśli w szczególności postulat powołania Rady Konstytucyjnej, mającej być organem pomocniczym wspomagającym głowę państwa w ochronie ustawy zasadniczej. Skoro Konstytucja przewiduje istnienie Rady Bezpieczeństwa Narodowego, to brak jest przeciwwskazań, aby podobny organ wspierał głowę państwa w zakresie realizacji zadania czuwania nad przestrzeganiem Konstytucji. Zgadzam się również z autorem, iż instytucja kontrasygnaty w polskim prawie konstytucyjnym wymaga daleko idącej reformy. Czy jednak faktycznie powinna ona iść tak daleko, jak formułowana przez D. Dudka propozycja, aby obowiązek uzyskania podpisu prezesa Rady Ministrów dotyczył tylko aktów enumeratywnie wyliczonych? Podobnie, akceptując potrzebę zmian w sposobie powoływania sędziów TK, 
nie jestem przekonany, iż faktycznie istotną poprawę w tym zakresie przyniosłoby powoływanie całego składu TK przez (wcale przecież nie apolityczną) głowę państwa.

Podsumowując niniejsze rozważania, uważam, iż pomimo zamieszczonych wyżej uwag krytycznych recenzowaną pozycję należy ocenić bardzo wysoko. Za największy walor książki D. Dudka uważam dobrze uargumentowane uwypuklenie roli, jaką głowa państwa odgrywa w systemie gwarancji poszanowania ustawy zasadniczej, będąc, jak to ujął autor, „nieodzownym elementem i zwornikiem” (s. 315). W moim przekonaniu w pracy powiódł się w pełni zamysł wykazania, iż próby deprecjacji roli ustrojowej prezydenta prowadzą w istocie także do osłabienia ochrony samej Konstytucji.

Recenzowana publikacja przyczynia się w sposób niewątpliwy do wypełnienia luki, jaką był w piśmiennictwie naukowym brak dostatecznej refleksji nad prezydenckim zadaniem czuwania nad przestrzeganiem Konstytucji. Tym samym, winna się ona stać lekturą obowiązkową dla wszystkich zainteresowanych zarówno problematyką pozycji ustrojowej głowy państwa, jak i zagadnieniem gwarancji dla ochrony ustawy zasadniczej.

Bartosz Szczurowski Uniwersytet Jagielloński w Krakowie 